\title{
PERKEMBANGAN RUANG LINGKUP ANTROPOLOGI HUKUM
}

NAMA

EMAIL

No. BP

PERGURUAN TINGGI
: SATRIA SALIM

: ardir735@gmail.com

: 2110003600266

: ILMU HUKUM

\section{A. PENDAHULUAN}

Pendidikan dapat diartikan sebagai suatu proses pembelajaran, pemberian pengetahuan, keterampilan dan sikap melalui pikiran, karakter serta kapasitas fisik dengan menggunakan pranata-pranata agar tujuan yang ingin dicapai dapat dipenuhi. Pendidikan dapat diperoleh melalui lembaga formal dan informal. Penyampaian kebudayaan melalui lembaga informal tersebut dilakukan melalui enkulturasi semenjak kecil di dalam lingkungan keluarganya. Dalam masyarakat yang sangat kompleks, terspesialisasi dan berubah cepat, pendidikan memiliki fungsi yang sangat besar dalam memahami kebudayaan sebagai satu keseluruhan.

Dengan makin cepatnya perubahan kebudayaan, maka makin banyak diperlukan waktu untuk memahami kebudayaannya sendiri. Hal ini membuat kebudayaan di masa depan tidak dapat diramalkan secara pasti, sehingga dalam mempelajari kebudayaan baru diperlukan metode baru untuk mempelajarinya. Dalam hal ini pendidik dan antropolog harus saling bekerja sama, dimana keduanya sama-sama memiliki peran yang penting dan saling berhubungan. Pendidikan bersifat konservatif yang bertujuan mengekalkan hasil-hasil prestasi kebudayaan, yang dilakukan oleh pemuda-pemudi sehinga dapat menyesuaikan diri pada kejadian-kejadian yang dapat diantisipasikan di dalam dan diluar kebudayaan serta merintis jalan untuk melakukan perubahan terhadap kebudayaan.

Antropologi adalah salah satu cabang ilmu sosial yang mempelajari tentang budaya masyarakat suatu etnis tertentu. Antropologi lahir atau muncul berawal dari ketertarikan orang-orang Eropa yang melihat ciri-ciri fisik, adat istiadat, budaya yang berbeda dari apa yang dikenal di Eropa. Di antara ilmu-ilmu sosial, dan alamiah, antropologi memiliki kedudukan, tujuan, manfaat yang unik karena bertujuan dan bermanfaat dalam merumuskan penjelasan-penjelasan tentang perilaku manusia yang didasarkan pada studi atas semua aspek biologis manusia dan perilakunya di semua masyarakat. setelah di kaji kita dapat mengemukakan hasilnya bahwa manfaat di dalam antropologi hukum sangat luas. Antropologi hukum telah memberikan kontribusi yang sangat besar bagi perkembangan ilmu hukum. Dan kesimpulan yang dapat diambil adalah dimana pun kita, kita tidak akan pernah jauh dari hukum selama kita berada di negara hukum.

\section{B. PEMBAHASAN}

Disiplin antropologi merupakan peradaban barat. Dari lembaga-lembaga antropologi etnografi, lahirlah Antropologi untuk pertama kali. Misalnya, lembaga 
Society Etnogiqui (Paris) 1839 oleh M.Edwards, The Etnological Society (London) oleh T.Hodgokin (anti perbudakan .Tujuan lembaga tersebut sebagai pusat pengumpulan dan studi bahan etnografi yang berasal dari banyak kebudayaan di dunia.Dua puluh lima tahun kemudian (1874) di London diterbitkan buku Notes and Queries in Anthropologi yang dipergunakan untuk menyusun pedoman dalam pengumpulan etnografi secara teliti.

Etnografi (ilmu tentang bangsa-bangsa) resmi diakui dunia tahun 1884 dengan diadakannya mata kuliah etnologi di universitas Oxford,inggris dengan E.B Tylor (ahli arkeologi peradaban yunani dan romawi kuno) sebagai dosen pertama. Di amerika serikat,etnologi resmi diakuidengan dibukanya Department of archeology and ethnologi di universitas Harvard tahun 1888.Dalam perkembamgannya ,lembaga etnologi di amerika terdesak dengan istilah antropologi sebagai ilmu tentang manusia dalam segala aspeknya,baik fisik maupun budayanya dari manusia dahulu sampai sekarang.

Lewis H Morgan (1818-1881) adalah perintis dan pelopor yang paling berpengaruh dalam ilmu antropologi dengan karya terbesarnya yang berjudul Ancient Society (1877) yang melukiskan proses masyarakat dan kebudayaan melalui delapan tingkat evolusi kebudayaan yang universal (zaman liar tua,zaman liar madya,zaman liar muda,zaman barbar tua,zaman barbar madya,zaman barbar muda,zaman peradaban baru,zaman perdaban masakini). Namun teori Morgan dikecam keras oleh antropolog inggris maupun amerika,sehingga tidak diakui dunia.sedangkan di uni soviet teori Morgan popular karena bersesuaian debgan ajaran Karl Marx dan F Engels mengenai evolusi masyarakat manusia .

Yang diakui sebagai bapak antropologi adalah Franz Boas yaitu antropolog kelahiran jerman ahli geografi yang menulis buku The Centural Eskimo (1888). Boas pun telah meletakkan konsepsi dasar yang sampai sekarang dianut oleh hampir seluruh universitas di amerika serikat yaitu kesatuan dari semua ilmu tentang manusia dan kebudayaan,yaitu ilmu paleoantropologi, antropologi fisik, arkeologi prasejarah. Etnolinguistik, dan antropologi budaya yang menjadi sub ilmu antropologi. Boas mengatakan bahwa ada perbedaan antara pencatat dan pengumpul bahan di daerah dan ahli pikir yang menganalisis bahan,jadi ahli etnografi yaitu juru catat saja sedangkan sarjana etnologi mahir dalam teori-teori mengenai seluk beluk masyarakt dan kebudayaan manusia.

Dalam buku antropologi sosial karya E.E.Evans Pritchard dijelaskan bahwa etnologi dan antropologi sosial memiliki tujuan yang berbeda walauupun kajiannya sama.tugas etnologi ialah mengelompokan manusia berdasarkan cirriciri ras dan kebudayaan mereka dan kemudian menguraiukan tentang penyebaran pada masa ini atau masa lalu melalui pergerakan dan percampuran manusia serta difusi kebudayaan.Sedangkan antropolgi sosial mempunyai tugas mengkaji tingkah laku sosial umumnya dalam bentuk yang telah dilembagakan seperti persaudaraan,sistem kekeluargaan,organisasi politik,tatacara hubungan antara semua lembaga tersebut. Manusia primitive ( masyarakat yang kurang maju dari kita dalam beberapa aspek,tetapi mereka sering kali lebih maju di bidang lainnya ).Manusia primitive (savage) inilah pada abad 18 sangat menarik perhatian para filsafah,himgga pada abad ke 19 ahli antropolog juga meminatinya karena 
manusia primitive memaparkan institusi2 di dalam bentuk yang paling sederhana,kebudayaan yang beragam dan masyarakat primitive lebih cepat berubah bahkan terhapus.Sistem-sistem sosial yang semakin pupus ini adalah variasi struktur yang unik.

Dalam antropologi terdapat 4 fase yang terjadi dalam perkembangan antropologi sebagai ilmu, yaitu:

1. Fase pertama

Fase ini terjadi sebelum tahun 1800, sekitar akhir abad 15 hingga awal abad 16 orang eropa mulai mengelilingi wilayah wilayah dikawasan Asia, Afrika dan Amerika, sejak saat dalam perkembanganya permukaan bumi ini mulai terkena pengaruh Negara-negara Eropa Barat. Dalam perkembanganya mulai terkumpul catatan, buah cerita laporan dan bukubuku kisah cerita dari para musafir, pelaut, pendeta penyiar agama dan pegawai pemerintah jajahan mengenai wilayah yang mereka datangi. Dalam buku-buku itu termuat mengenai deskripsi bangsa-bangsa yang terdapat di Afrika, Asia, Oseania dan suku-suku bangsa lainnya. Bahanbahan deskripsi tersebut sangat menarik perhatian bangsa Eropa karena perbedaan dari wilayah yang dikunjungi dengan adat istiadat, bahasa, susunan masyarakat dan cirri-ciri fisik bangsa-bangsa Eropa Barat.

Bahan-bahan pengetahuan tadi disebut etnografi, atau seskripsi tentang bangsa-bangsa. Deskripsai yang diperoleh tadi biasanya tidak begitu teliti sehingga seringkali bersifat kabur, dan kebanyakan hanya memperhatikan hal yang menurut orang Eropa nampak aneh saja, walau ada pula karangan-karangan yang baik dan bersifat lebih teliti.

Dari keanehannya, maka bahan etnografi tadi amat menarik perhatian kaum terpelajar di Eropa Barat sejak abad ke 18. Kemudian dalam pandangan orang Eropa munculah pertentyangan terhadap bangsa Amerika, Afrika Asia dan juga Oseania tadi, yaitu: sebagian orang eropa menganggap bahwa mereka keturunan iblis dan bukan bangsa yang merupakan keturunan manusia, adajuga yang menganggap mereka merupakan bangsa yang masih murni yang belum tersentuh olehkejahatan, dan yang terakhir sebagian orang Eropa tertarik akan adat-istiadat dan ulai mengumpulkan benda-benda kebudayaan asal Amerika, Afrika, Oseania dan Asia sehingga muncul museum-museum kebudayaan luar Eropa.

Pada awal abad ke-19 pehartian terhadap himpunan pengetahuan tentang masyarakat, adat istiadat dan cirri-ciri fisik bangsa-bangsa di luar Eropa dari pihak dunia ilmiah menjadi sangat besar, demikian besarnya sehingga timbul usaha-usaha pertama dari dunia ilmiah untuk mengintegrasikan seluruh himpunan bahan pengetahuan etnografi tadi menjadi satu.

2. Fase Kedua

Masa ini berlangsung pada pertengahan abad ke-19, pada mas ini mulai muncul tulisan-tulisan ataupun berupa karangan yang menyusun bahan etnhografi tersebut berdasarkan cara berikir evolusi masyarakat. Secara singkat kerangka berfikir tersebut bisa di golongkan seperti berikut: Masyarakat dan kebudayaan manusia telah berevolusi dengan sangat 
lambat dalam jangka beribu-ribu taun dengan berbagai tingkatan evolusi, dengan sebagai patokan tingkatan tertinggi adalah masyarakat yang hidup seperti masyarakat dii Eropa Barat. Bentuk masyarakat yang tinggal di luar Eropa disebut oleh mereka(orang Eropa) sebagai bangsa primitive, dianggap sebagai sisa-sisa kebudayaan terdahulu yang masih hidup hingga sekarang.berdasarkan kerangka berfikir tersebut maka pada tahun sekitar 1860 timbul beberapa karangan yang membandingkan tingkat kebudayaan dari masing-masing bangsa berdasar tingkat-tingkat evolusi, sehingga timbula ilmu antropologi.

Kemudian timbul pula beberapa karangan yang hendak meneliti sejarah penyebaran kebudayaan bangsa-bangsa di mika bumi. Disini pula orang Eropa masih menganggap kebudayaan diluar Eropa merupakan sisasisa kebudayaan terdahulu yang masih kuno, sehingga dengan meneliti kebudayaan tersebut maka mereka dapat mengetahui sejarah penyebaran kebudayaan manusia. Dengan demikian dapat di simpulkan bahwa fase perkembangannya yang kedua ini ilmu antropologi berupa suatu ilmu akademikal; dengan tujuan yang dapat dirumuskan sebagai berikut: mempelajari masyarakat dan kebudayaan primitive dengan maksud untuk mendapat ssuatu pengertian tentang tingkat-tingkat kuno dalam sejarah evolusi dan sejarah penyebaran kebudayaan manusia.

\section{Fase Ketiga}

Fase ini berlangsung pada permulaan abad ke-20. Pada permulaan abad ke-20, sebagian besar negara-negara penjajah di Eropa masingmasing berhasil untuk mencapai kemantapan kekuasaannya di daerahdaerah jajahan di luar eropa. Untuk keperluan daerah jajahan dimana pada waktu itu mulai berhadapan ilmu antropologi sebagai suatu ilmu yang justru mempelajari bangsa-bangsa di daerah luar eropa justru menjadi sangat penting. Sejak itu timbul pendirian bahwa mempelajari bangsabangsa di luar Eropa itu penting.

Suatu ilmu antropologi dengan sifat-sifat seperti yang terurai di atas terutama berembang di negara Inggris sebagai negara penjajah yang utama, tetapi juga di hamper semua negara colonial lainnya. Selain itu ilmu antropologi di Amerika Serikat yang bukan negara colonial tetapi mengalami berbagai masalah yang berhubungan dengan suku-suku bangsa Indian yang merupakan suku asli atau penduduk pribumi Benua Amerika kemudian terpengaruh oleh ilmu antropologi yang baru tadi. Dalam fase ketiga ini ilmu antropologi menjadi suatu ilmu yang praktis dan tujuannya dapat dirumuskan sebagai berikut : Mempelajari masyarakat dan kebudayaan suku-suku bangsa di luar Eropa guna kepentingan pemerintah colonial dan guna mendapat suatu pengertian tentang masyarakat masa kini yang kompleks.

\section{Fase Keempat}

Fase ini kira-kira sesudah 1930. Pada fase ini ilmu antropologi mengalami masa perkembangannya yang paling luas. Hal ini termasuk bertambahnya bahan pengetahuan yang jauh lebih teliti, maupun mengenai ketajaman dari metode-metode ilmiahnya. Kecuali itu kita lihat adanya 
dua perubahan di dunia, yaitu timbulnya anti pati terhadap kolonialisme terhadap perang dunia II, serta cepat hilangnya bangsa-bangsa primitif (dalam arti bangsa-bangsa asli dan terpencil dari pengaruh kebudayaan Eropa dan Amerika) yang sekitar tahun 1930 mulai hilang, dan sesudah perang dunia II memang hampir tak adalagi di muka bumi.

Proses tersebut menyebabkan seolah-olah lapangan dalam ilmu antropologi telah hilang, sehingga memunculkan sebuah dorongan untuk memunculkan ide untuk mengembangkan lapangan penelitian dengan ide dan tujuan baru. Adapun bahan-bahan etnografi yang terdapat dalam fase pertama, kedua maupun yang ketiga tidak dibuang begitu saja melainkan dijadikan sebagai landasan bagi perkembangannya yang baru. Pengembangan itu terjadi di amerkia Serikat tetapi menjadi umum di negara-negara lain setelah tahun 1951, stelah 60 orang ahli antropologi dari berbagai negara Amerika dan Eropa, menajlin seuatu simposium internasional untuk meninjau dan merumuskan pokok tujuan ruang lingkup dari ilmu antropologi yang baru.

Mengenai tujuannya, ilmu antropologi yang baru dalam fase perkrmbangannya yang keempat ini dapat dibagi dua yaitu tujuan akademikal dan tujuan praktisnya. Tujuan akademuikalnya adalah mencapai pengertian tentang makhluk-makhluk manusia pada umumnya dengan mempelajari aneka warnabentuk fisiknya, masyarakat, serta kebudayaannya. Karena disalam praktek ilmu antropologi biasanya mempelajari masyarakat suku bangsa, maka tujuan praktisnya adalah mempelajari manusia dalam aneka warna masyarakat suku-bangsa guna membangun masyarakat suku bangsa itu.

\section{PENUTUP}

Antropologi adalah salah satu cabang ilmu sosial yang mempelajari tentang budaya masyarakat suatu etnis tertentu. Antropologi lahir atau muncul berawal dari ketertarikan orang-orang Eropa yang melihat ciri-ciri fisik, adat istiadat, budaya yang berbeda dari apa yang dikenal di Eropa.

\section{DAFTAR PUSTAKA}

Darmini Roza dan Laurensius Arliman S, Peran Pemerintah Daerah Di Dalam Melindungi Hak Anak Di Indonesia, Masalah-Masalah Hukum, Volume 47, Nomor 1, 2018. https://doi.org/10.14710/mmh.47.1.2018.10-21

Laurensius Arliman S, Peranan Metodologi Penelitian Hukum di Dalam Perkembangan Ilmu Hukum di Indonesia, Soumatera Law Review, Volume 1, Nomor 1, 201. http://doi.org/10.22216/soumlaw.v1i1.3346.

Laurensius Arliman S, Peran Badan Pemusyawaratan Desa di Dalam Pembangunan Desa dan Pengawasan Keuangan Desa, Padjadjaran Journalof Law, Volume 4. 